\title{
BANKING INDUSTRY CONCENTRATION AND NET INTEREST MARGINS (NIMs) IN PAKISTAN
}

\author{
Ijaz Hussain \\ Department of Economics, School of Liberal Arts and Social Sciences, Beaconhouse National \\ University, Lahore-Pakistan, 3-C Zafar Ali Road, Gulburg V, Lahore, 54000 Pakistan \\ E-mail: ijaz.hussain@bnu.edu.pk
}

Received 13 June 2012; accepted 17 September 2012

\begin{abstract}
This paper uses bank level data of 26 commercial banks for the period 2001-2010 to explore determinants of net interest margins of commercial banks of Pakistan. Based on results of this study, past net interest margins, bank soundness, operating cost, industry concentration, relative market share, inflation, real depreciation and industrial growth have statistically significant and positive impact while diversification, change in bank size, lagged liquidity, stock market development have dampening effects on net interest margins. However, impact of ownership, GDP and credit market development is statistically insignificant.

Our regression results suggest that stock market development as means of alternative source of finance contributes to reduction in net interest margins while the impact of banking sector development on breaking banking cartels and bringing net interest margins down had been insignificant. Exchange rate adjustments, rate of inflation and growth of the industry also cannot be ignored in management of net interest margins. Incentives for bank executives and managers to ensure efficiency in operating costs, reduction in the premium charged for bank soundness, diversification of bank activities and passing on the scale efficiencies to both depositors and borrowers can also play role to bring interest margins down to accelerate investment and growth in the country.
\end{abstract}

Keywords: net interest margin, market power, Pakistan, concentration ratio, commercial banks, banking industry.

Reference to this paper should be made as follows: Hussain, I. 2014. Banking industry concentration and net interest margins (NIMs) in Pakistan, Journal of Business Economics and Management 15(2): 384-402.

JEL Classifications: C33, G21, L11.

\section{Introduction}

Persistently high interest margins are reflective of higher intermediation costs to the society and might be indicative of systematic problems like concentrated banking industry, perceived market and credit risks, bank unsoundness, scale diseconomies, high operating costs, unfavourable institutional environment and distortions in markets (Poghosyan 2012). Evidence on impact of net interest margins (NIMs) on economy 
is well-pronounced and documented in literature. Jayaatne and Strahan (1996), Rajan and Zingales (1998) and Beck et al. (2000) provide evidence on repercussions of intermediation costs (and hence NIMs) on economic activity. Khediri and Ben-Khedhiri (2011) highlight that net interest margin, among other variables; can impede economic activity of a country. Well functioning intermediaries support growth of the economy (Levine 1997), therefore, net interest margins (NIMs) are indicative of the efficiency/ effectiveness of the intermediaries to channelize the funds in the system (Tan 2012). As substantiated in Hadad et al. (2003) and Saunders and Schumacer (2000) low NIMs are also indicative of effectiveness of monetary policy and financial stability; and competitive banking system respectively. As discussed in Sidabalok and Viverita (2012), level of NIMs measures expected social cost of intermediation to be borne by public. Above discussion highlights the role and significance of NIMs for economic growth of a country. Therefore, it is imperative and quite pertinent to examine the determinants of NIMs to develop appropriate policy interventions. In addition, understanding of the determinants of NIMs assists us in monitoring the efficiency of the financial intermediaries (Hawtrey, Liang 2008).

We note consistently growing net interest income ${ }^{1}$ (Fig. 1) and fairly high interest spread ratio $^{2}$ (Fig. 2) of the banking industry in Pakistan. We also note a very high dispersion in interest spread ratio ranging from $38.3 \%$ in 2001 to as high as $68.9 \%$ in 2004 followed by continuous decline to $45.8 \%$ in 2010 . Such sizable interest spreads and net interest margins ${ }^{3}$ (NIMs) (Figs 1, 2, 3) also appear to have significant impact on profitability of the banking industry. Consistently high net interest margins (NIMs) also appear to be partly responsible for inhibiting or retarding economic growth in the country (Fig. 3). These preliminary interesting findings become a basis for this study to

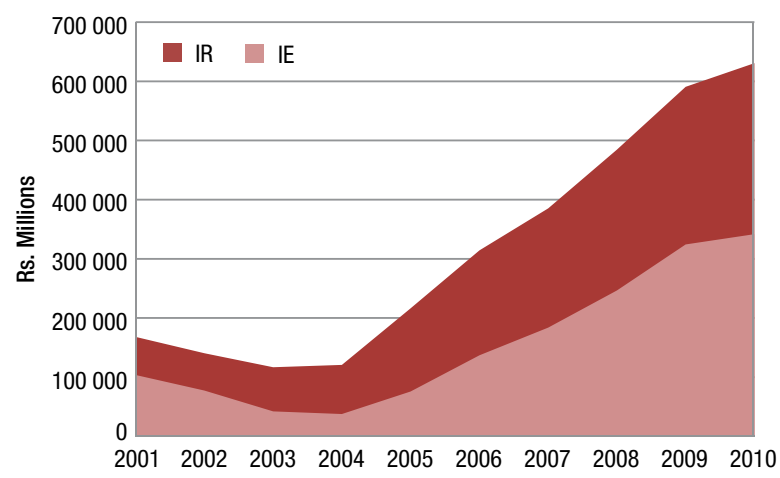

Fig. 1. Net Interest Income* of the Banking Industry

Note: *(Interest Revenue (IR)-Interest Expense (IE)

Source: Banking Statistics of Pakistan (Various Issues).

\footnotetext{
${ }^{1}$ Interest Revenue (IR) minus interest expense (IE) of the banking industry.

${ }^{2}$ Net interest income as a percentage of interest revenue of the banking industry.

${ }^{3}$ Net interest income as a percentage of total assets of the banking industry.
} 


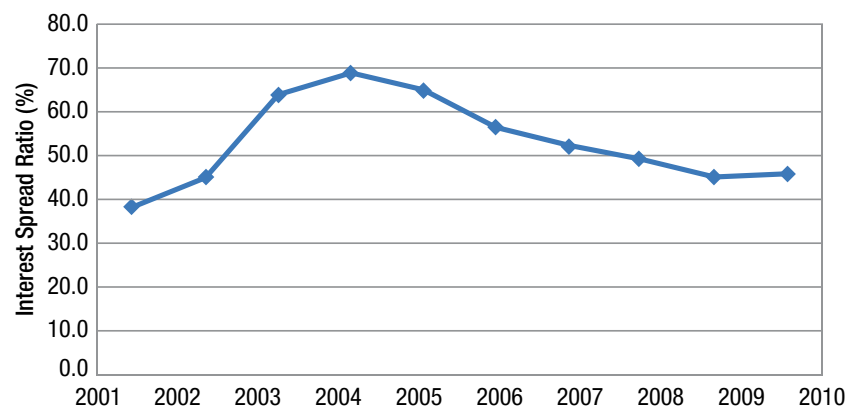

Fig. 2. Interest Spread Ratio (\%)

Source: Banking Statistics of Pakistan (Various Issues).

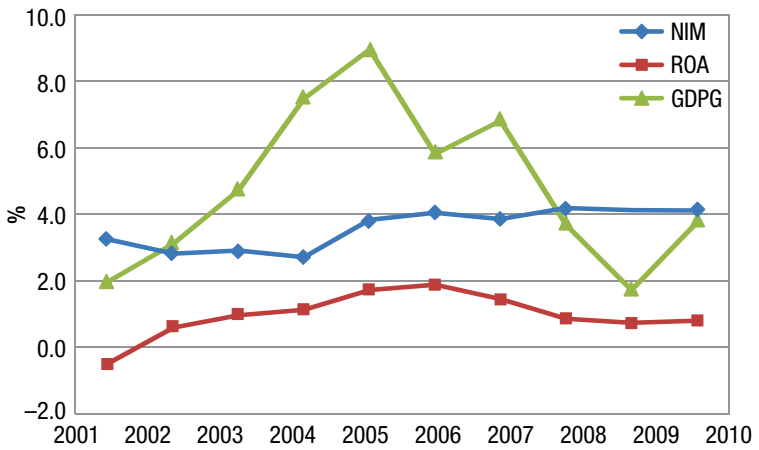

Fig. 3. Growth (GDPG), Net Interest Margins (NIMs) and Profitability (ROA) Source: Banking Statistics of Pakistan (Various Issues), Hand Book on Statistics of Pakistan Economy (2010).

explore the factors which drive net interest margins in the banking industry of Pakistan. This will also assist us to draw policy inferences to manage economic growth and efficiency of financial intermediaries.

Rest of the paper is organized as follows: Section 1 reviews literature. Section 2 identifies data sources, variables, research design and methodology. The last section presents findings.

\section{Review of the literature}

Männasoo (2012) highlights that the recent global financial turmoil increased bank interest spreads in Estonia to the highest levels recorded since the Russian crisis in 1998. Findings indicate that the regulatory, efficiency and bank-portfolio effects share almost equal weight in the observed spread, whereas credit risk shares an insignificant share to the mark-up. Strong liquidity and foreign capital permit lower spreads in Estonia.

Hamadi and Awdeh (2012) analyze the determinants of commercial bank interest margins in Lebanon using bank-specific, industry specific, monetary policy, and macroeconomic variables for the period 1996-2009. The empirical results indicate that for 
domestic banks, size, liquidity, efficiency, and to a lower extent, capitalization and credit risk have a negative impact on interest margins while the growth rate of deposits, lending, inflation, central bank discount rate, national saving, domestic investment, and to a lower degree, the interbank rate, all have a positive impact on net interest margins. For foreign banks on the other hand, they identify that size, liquidity, capitalization, and credit risk, do not show a significant impact. They also highlight that the host market macroeconomic conditions, industry characteristics, central bank discount rate, and interbank rate, have much weaker impact for foreign bank interest margins.

Using bank level data, Haruna (2012) shows that financial intermediation, operating expenses and loan loss provision are the three most common factors that determine the commercial bank interest rate spread whether measured using narrow or broad definitions of interest rate spreads in Nigeria.

Naceur and Goaied (2008) examine the impact of banks' characteristics, financial structure and macroeconomic indicators on banks' net interest margins and profitability in the Tunisian banking industry for the 1980-2000 period. They conclude that individual bank characteristics explain a substantial part of the variation in bank interest margins and net profitability while macroeconomic variables have no impact on Tunisian banks' profitability. They associate high profitability of banks with bank capitalization, overheads, stock market development and private bank ownership and identify negative coefficient with size.

Sufian and Habibullah (2009) investigate the determinants of the profitability of the Chinese banking sector during the post-reform period of 2000-2005. The empirical findings suggest that all the determinants variables have statistically significant impact on China banks' profitability, however, the impacts are vary across bank types. Liquidity, credit risk, and capitalization have positive co-efficient on the state owned commercial banks' profitability, while the impact of cost is negative. Joint stock commercial banks with higher credit risk tend to be more profitable, while higher cost results in a lower profitability. The empirical findings also suggest that size and cost results in a lower city commercial banks' profitability, while the more diversified and relatively better capitalized tend to exhibit higher profitability. The impact of economic growth is positive, while growth in money supply is negatively related to both the state owned commercial banks' and city commercial banks' profitability.

Using quarterly data (1976-1979) of 100 US banks, Ho and Saunders' (1981) included some bank-specific variables, including implicit interest payment, opportunity cost of required reserves, and default premium and the constant term represented a 'pure spread' not explained by bank-specific characteristics. A regression of this 'pure spread' was subsequently estimated as a function of the variance of interest rates. This work was replicated and extended for other time periods, regions and countries. Angbazo (1997) extended the work of Ho and Saunders' (1981) by including bank- and country-specific variable including credit risk, implicit interest payments, interest rate risk, Lerner Index (measure of market power), operating costs, opportunity cost of required reserves, quality of management and bank capital. 
In a cross country analysis of 80 countries, Demirgüç-Kunt and Huizinga (1999) include taxes, foreign ownership and macroeconomic variables along with bank-specific factors as potential determinants of NIMs. Demirgüç-Kunt et al. (2003) use data of 1400 banks from 72 countries and conclude that concentration, bank equity, reserve requirement, inflation, and state ownership bank entry and activity restrictions have positive impact on NIMs while bank size, liquidity, fee income (non-interest income), GDP growth are negatively associated with net interest margins.

Gounder and Sharma (2012) conclude that NIM has a positive association with implicit interest payment (non-interest expense on deposits), operating cost, market power and credit risk, and a negative association with the quality of management and liquidity risk. However, the association with bank capital and opportunity cost of required reserves do not conform to expectations. Bank level analysis in Tatum Tan (2012) suggests that interest margins in Philippines rise with bank size, bank capitalization, foreign ownership, overhead costs, stock market development and tax rates while higher growth, lower inflation, higher reserve requirements, greater banking sector development and lower government deficits reduce net interest margins in a number of Asian economies.

Using bank level data of 29 commercial banks of Pakistan from 1998 to 2005, Khawaja and Din (2007) find that, among macroeconomic/industry specific variables, bank industry concentration and inflation have negative and statistically insignificant impact on interest spreads while GDP growth has significant negative impact. Real interest rate and interest-insensitivity of deposits, however, have positive and significant coefficients. On the other hand, among bank specific variables, liquidity, market share, administrative cost and non-performing loans have positive and significant impact, however, equity have positive but insignificant coefficient.

This is pertinent to note that, in context of Pakistan, Khawaja and Din (2007) have not captured the impact of bank size, ownership structure, diversification of the bank activities, real depreciation, stock market and financial/banking sector development on interest spread in Pakistan.

This paper fills the void identified in last Para in literature on NIMs in Pakistan. In addition, it includes the impact of bank soundness i.e. distance to default (a consolidated measure of capital adequacy, profitability and risk) on NIMs and extends the analysis of NIMs in Pakistan to recent period from 2001 to 2010.

\section{Research design and methodology}

\subsection{Data set and sampling}

This study uses Banking Statistics of Pakistan (2010) as main data source in addition to Hand Book on Statistics of Pakistan Economy (2010), Financial Statements Analysis of Companies (Non-Financial) Listed at Karachi Stock Exchange (Various Issues, 2001-2010), Financial Statements Analysis of Financial Sector (Various Issues, 2001-2010) published by Statistics and DWH Department of State Bank of Pakistan and World Development Indicators. Sample for this study includes all banks with consistent and complete 10 years data series from 2001 to 2010 . The banks with inconsistent or incomplete data series are excluded from the analysis. 


\subsection{Choice and description of variables}

NIM is independent variable in this study. Table 1 presents the list, symbols and brief description of explanatory variables for credit growth.

Bank soundness is measured by estimating the distance to default (DD) of a bank (Igan, Pinheiro 2011). Distance to default is calculated as follows:

$$
D D_{i, t}=\left(R O A_{i, t}+C R_{i, t}\right) / S D_{i},
$$

where $R O A$ is Return on Assets, $C R$ is Capital Ratio and $S D$ is the Standard Deviation of $R O A$ of bank " $i$ ". $R O A$ is a measure of profitability and is Profit after Tax as a percentage of Total Assets of the bank while Capital Ratio is ratio between total equity (including Share Capital, Un-appropriated Profits, Reserves and Surplus/Deficit on Revaluation of Assets) and Total Assets of the bank. This captures capital adequacy of banks. Standard Deviation ${ }^{4}$ of $R O A$ is indicative of the long term risk faced by a bank. Based on Equation (1) above higher profitability $(R O A)$, higher Capital Ratio $(C R)$ and a lower dispersion of profitability of banks will give rise to a higher distance from default and therefore indicate soundness of banks and vice versa. Bank soundness is likely to have positive impact on NIMs because bank may like to discount the returns to risk averse depositors for providing financial stability, secure profitability and lower risk.

As pointed out in Tatum Tan (2012) impact of bank size on NIMs may not be clear. This may be attributable to monopoly power of bigger banks on one hand and on the other hand bigger bank size may act as a sign of credibility and stability and thus a motivating factor for depositors to accept low interest rates on deposits. Demirgüç-Kunt, Laeven and Levine (2003) attribute lower NIMs to the economies of large scale for bigger banks. Relative size of the bank is measured as follows:

$$
R B S_{i, t}=\frac{T A_{i, t}}{O T A_{I, t}} \times 100,
$$

where $R B S_{i}$ relative size of bank " $i$ " $T A_{i, t}$ is total assets of a bank " $i$ " in time period " $t$ " while $O T A_{I, t}$ measures overall total assets of the banking industry in period " $t$ ".

Following Gounder and Sharma (2012) we take ratio of the sum of cash, balances with treasury and other banks to total assets as proxy for liquidity of bank. Khawaja and Din (2007) identify positive relationship between liquidity and interest spread in Pakistan. They attribute this relationship to less appetite for more deposits of a bank with surplus liquidity and hence low returns on deposits and higher interest spread while Poghosyan (2012) argues that higher liquidity implies higher opportunity of holding extra liquidity which in turn raises NIMs. Doliente (2005), and Gounder and Sharma (2012) identify negative relation between liquidity and NIMs in Southeast Asia and Fiji respectively. Surplus liquidity may force banks to charge lower interest on loans and thus reduced NIMs.

This study uses dummy variables to identify bank ownership. D1 = 1 for a local bank (incorporated in Pakistan) and 0 for a foreign bank (incorporated outside Pakistan) and

\footnotetext{
${ }^{4}$ Calculated for 10 years ROA.
} 
Table 1. List, symbols and proxies of variables

\begin{tabular}{|c|c|c|c|}
\hline $\begin{array}{l}\text { S. } \\
\text { NO. }\end{array}$ & Variable & Symbol & Proxy \\
\hline \multicolumn{4}{|r|}{ Dependent variable: } \\
\hline \multirow[t]{2}{*}{1} & \multirow{2}{*}{$\begin{array}{l}\text { Net interest } \\
\text { margin }\end{array}$} & NIM & Intrest Revenue $_{i, t}-$ Interest Expense $_{i, t} \times 100$ \\
\hline & & & Total Asssets $_{i, t}$ \\
\hline \multicolumn{4}{|c|}{ Explanatory variables: } \\
\hline \multicolumn{4}{|c|}{ A. Bank-/Bank industry-specific variables: } \\
\hline 2 & $\begin{array}{l}\text { Net interest } \\
\text { margin* }\end{array}$ & NIM $(-1)$ & \\
\hline 3 & Bank soundness & $\mathrm{BS}$ & Distance to default $* *$ \\
\hline 4 & $\begin{array}{l}\Delta \text { Relative bank } \\
\text { size }\end{array}$ & $\Delta \mathrm{RBS}$ & $\begin{array}{l}\text { Change in relative size of book value of total assets } \\
\text { of the bank. }\end{array}$ \\
\hline 5 & Bank liquidity* & $\mathrm{BL}(-1)$ & $\begin{array}{l}\text { Ratio of the sum of cash balances and balances } \\
\text { with other banks to total assets }\end{array}$ \\
\hline \multirow[t]{2}{*}{6} & Bank ownership & D1 & $\begin{array}{l}\text { D1 = } 1 \text { for a foreign bank (i.e. incorporated outside } \\
\text { Pakistan) and } 0 \text { for a domestic bank (i.e. incorporated } \\
\text { inside Pakistan) }\end{array}$ \\
\hline & & D2 & $\mathrm{D} 2=1$ for a public sector bank and 0 for a private bank \\
\hline 7 & Operating cost & $\mathrm{OC}$ & Administrative cost per employee \\
\hline 8 & Diversification & $\mathrm{D}$ & Proportion of non-interest income in total income \\
\hline 9 & Market share & MS & $\begin{array}{l}\text { Relative market shares in advances [(net of provisions } \\
\text { for non-performing loans and actual write offs of bad } \\
\text { debts) including lending to other financial institutions] }\end{array}$ \\
\hline 10 & $\begin{array}{l}\text { Industry } \\
\text { concentration }\end{array}$ & IC & $\begin{array}{l}\text { Herschman-Herfindhal Index (HHI) i.e. Sum of the } \\
\text { squared market shares of advances [(net of provisions } \\
\text { for non-performing loans and actual write offs of bad } \\
\text { debts) including lending to other financial institutions } \\
\text { of all banks] }\end{array}$ \\
\hline
\end{tabular}

B. Macroeconomic or non-financial industry-specific variables:

\begin{tabular}{clcl}
\hline 1 & Economic growth & EG & Growth rate of GDP \\
\hline 2 & $\begin{array}{l}\text { Stock market } \\
\text { development }\end{array}$ & SMD & Market Capitalization to GDP Ratio \\
\hline 3 & $\begin{array}{l}\text { Credit market } \\
\text { development }\end{array}$ & CMD & $\begin{array}{l}\text { Ratio between advances of the banking industry } \\
\text { to GDP }\end{array}$ \\
\hline 4 & $\begin{array}{l}\Delta \text { Real } \\
\text { depreciation* }\end{array}$ & $\Delta$ RD (-1) & Index for real effective exchange rate \\
\hline 5 & Inflation & INF & Rate of inflation \\
\hline 6 & Industrial growth & IG & $\begin{array}{l}\text { Growth rate of overall gross sales of the non-financial } \\
\text { industry }\end{array}$ \\
\hline
\end{tabular}

Notes: *lagged for one year; **Please see the following section for measurement of distance to default. 
D2 = 1 for a public sector bank and 0 for a private bank. Demirgüç-Kunt and Huizinga's (1999) substantiate positive relationship of foreign ownership with NIMs on account of technological edge especially in developing countries. However, as pointed out in Tan (2012), better technology may imply greater efficiency for foreign banks and allow them to have lower NIMs. Profit motive of private banks is likely to raise NIMs in private banks as compared to those in public sector banks.

Banks are able to pass on operating overhead (administrative) costs to their customers (Demirgüç-Kunt, Huizinga (1999); Doliente (2005)) therefore operating/administrative costs would have positive impact on NIMs. We use administrative cost per employee as a proxy for operating costs. Sidabalok and Viverita (2012) use total loans to total assets ratio as proxy for bank specialization and identify positive relation with NIMs in Indonesia. Alternatively proportion of non-interest revenue in total revenue ${ }^{5}$ of a bank serves an interesting proxy for diversification of bank activities. We expect diversification to have negative impact on NIMs.

Khawaja and Din (2007) attribute positive relation between bank's market share and NIM to higher market power in Pakistan and negate the concept that scale efficiencies reduce operating costs and thus result in lower interest spread. At the same time they surprisingly identify negative and statistically insignificant coefficient with banking industry concentration. We calculate the relative market share of a bank as follows:

$$
M S_{i, t}=\frac{A_{i, t}}{A_{B I, t}},
$$

where $M S_{i, t}$ represents market share of bank $i$ in time period $t, A_{i, t}$ denotes the sum of lending of a bank to other financial institutions and advances (net of provisions for non-performing loans and actual write offs of bad debts) of a bank and $A_{B I, t}$ denotes the sum of lending of a all banks to other financial institutions and advances of the overall banking industry. Alternate approaches (i.e. n-firm concentration ratio, Lerner Index or Herschman-Herfindhal Index $(H H I)$ ) may be used to calculate banking industry concentration. Calculation of the banking industry concentration may be based on shares of deposits or advances or total assets or interest revenue or profits after tax. We use advances [(net of provisions for non-performing loans and actual write offs of bad debts) including lending to other financial institutions] to calculate HerschmanHerfindhal Index $(H H I)$ as follows:

$$
H H I_{t}=\sum_{i=1}^{n} S_{i, t}^{2},
$$

where $\mathrm{HHI}_{t}$ is Herschman-Herfindhal Index (HHI), $S_{i, t}$ denotes market share of the advances of bank $i$ during time period $t$ and $i=1$ to $n$ number of firms.

As highlighted in Sidabalok and Viverita (2012) and references therein, NIMs may be pro-cyclical (Claeys, Vennet 2008) or counter-cyclical (Sidabalok, Viverita 2012; Gelos 2006) to GDP. Khawaja and Din (2007) find interest spread as counter-cyclical to GDP

\footnotetext{
${ }^{5}$ Interest plus non-interest revenue.
} 
in Pakistan. Brock and Rojas (2000) conclude that rising inflationary pressures are reflected in higher NIMs in Latin America.

Tan (2012), Demirgüç-Kunt and Huizinga (2000) and Aysan et al. (2010) show that banking or financial sector development signifies intense competition and, therefore, has negative influence on NIMs. As discussed in Tan (2012), improved stock market development provides an alternate opportunity to finance for companies and thus is likely to reduce the market power of banks in credit market resulting in lower NIMs on the other hand, through improvement in stock market development banks are better informed about a pool of prospective borrowers which in turn reduces lending costs and enables banks to have higher NIMs. Findings in Tan (2012) and Demirgüç-Kunt and Huizinga (2000) are consistent with this latter complementarities hypothesis.

Financial Stability Review (2011) of the European Central Bank identifies three channels (namely balance sheet channel, competitiveness channel and foreign currency lending channel) through which exchange rates can influence non-performing loans which in turn may also affect credit growth and hence NIMs. Hacker, Kim and Månsson (2010) substantiate negative relationship between the spot exchange rate (domestic-currency price of foreign currency) and the nominal interest rate differential (approximately the domestic interest rate minus the foreign interest rate) at the shortest time scales, while a positive relationship is shown at the longest time scales. To best of my knowledge, most of the previous studies have not included real depreciation (real effective exchange rate) as determinant of NIMs. High inflation indicative of riskier financial market is likely to raise interest margins (Tan 2012). Demirgüç-Kunt and Huizinga (1999) attribute this positive relationship to prospects of higher income from bank floats or delays in crediting client accounts.

Annual growth rate gross sales of the overall industry from Financial Statements Analysis of Companies (Non-Financial) Listed at Karachi Stock Exchange (Various Issues, 2001-2010) serves as proxy for industrial growth. Growth of the industry is measured as annual percentage change in gross sales of the industry as a whole:

$$
I G_{t}=\frac{\sum_{i=1}^{n} G S_{i, t}-\sum_{i=1}^{n} G S_{i, t-1}}{\sum_{i=1}^{n} G S_{i, t}} \times 100 .
$$

Growth of industry would drive demand for loans up and thus is expected to raise NIMs. To best of knowledge, no other study has included the impact of the growth of non-financial industry on NIMs so far.

\subsection{Methodology}

This study uses highly popular statistical model of panel data analysis that combines cross section and time series data and estimates pooled least squares regression of a standard model in the following form:

$$
N I M_{i t}=\beta_{0}+\beta_{1} X_{i t}+\beta_{2} Z_{t}+\mathrm{e}_{i t},
$$

where $N I M_{i t}$ denotes net interest margin of bank $i$ while $t$ specifies time dimension. $\beta_{0}$, $\beta_{1}$ and $\beta_{2}$ are unknown constants. $X_{i t}$ represents the set of bank-specific explanatory 
variables for banks which vary across banks as well as over time. $Z_{t}$ is the set of macroeconomic or overall bank/non-financial industry wide explanatory variables that are common for all banks and vary over time only. $\mathrm{e}_{i t}$ is white noise error term.

\section{Findings and conslusions}

Summary Statistics of these variables are presented in Table 2. Correlation Coefficients are presented in Table 3 to rule out perfect multi-co-linearity. Regression Results of the model are presented in Table 4.

Our regression results indicate that feedback effect of past NIMs on current NIMs is positive and significant. It is interesting to not positive coefficient with bank soundness. This signifies the fact that sound banks take an advantage of the risk averse behavior of the depositors and pay lower interest rates on deposits in exchange for ensuring secure profitability, capital adequacy and lower risk. Bigger banks on the hand enjoy scale efficiencies and are cost efficient and; hence, can afford to have lower NIMs.

Negative sign with bank liquidity with a one year lag is indicative of the fact that the banks charge lower interest on lending and thus reduce NIMs to utilize their surplus funds. Our results contradict to the finding in Khawaja and Din (2007).

Consistent with the results in Sidabalok and Viverita (2012), Gounder and Sharma (2012), Khawaja and Din (2007) cost in-efficient banks maintain higher NIMs to cover up their operating costs by passing these on to their customers. Foreign ownership has positive (consistent with the results in Tan (2012) while public ownership of banks has negative impact on NIMs. However ownership effects are statistically insignificant in our model. A larger proportion of non-interest income in total income of a bank representing diversification in banks' activities results in lower NIMs because banks focus on other activities to enhance their profitability.

Positive and significant coefficient with industry concentration signifies that concentration of market power has led to high interest NIMs in Pakistan. Our results are in line with the findings in Tan (2012), Gounder and Sharma (2012) ${ }^{6}$, Sidabalok and Viverita (2012). This view, however, contradicting to the results in Khawaja and Din (2007) ${ }^{7}$, is further supported by positive and significant coefficient of relative market share. It is pertinent to note that $1 \%$ increase in the market share adds $1.5 \%$ to net interest margin of that bank, this also justifies further need for strong action of ant-trust authority to break down the bank cartels to bring NIMs down to accelerate economic growth in the country.

All macroeconomic variables (excluding economic growth and credit market development) are also statistically significant. Consistent with Claeys and Vennet (2008) NIMs are pro-cyclical in Pakistan. However our results contradict with those in Gelos (2006), Sidabalok and Viverita (2012), Tan (2012) and Khawaja and Din (2007) ${ }^{8}$.

\footnotetext{
${ }^{6}$ However, used Lerner Index (LI) for industry concentration.

${ }^{7}$ However, Khawaja and Din (2007) used Herschman-Herfindhal Index (HHI).

${ }^{8}$ However, Khawaja and Din (2007) use interest spread instead of NIM as dependent variable.
} 


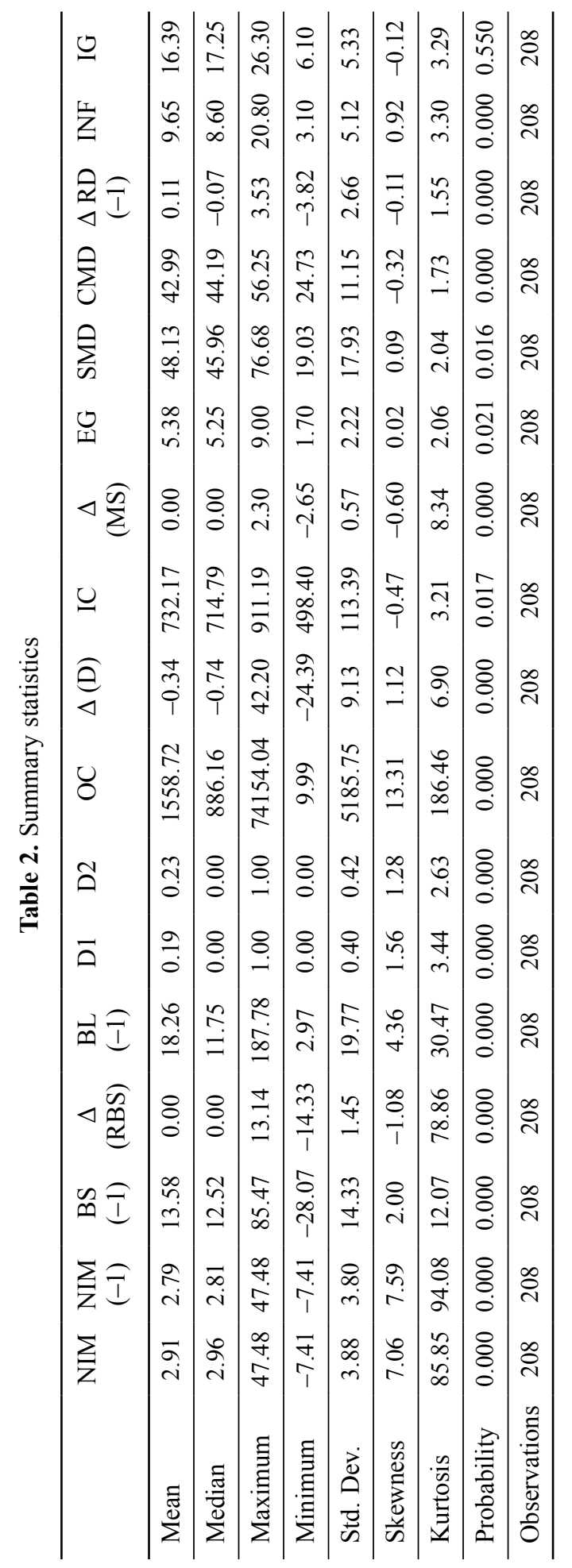




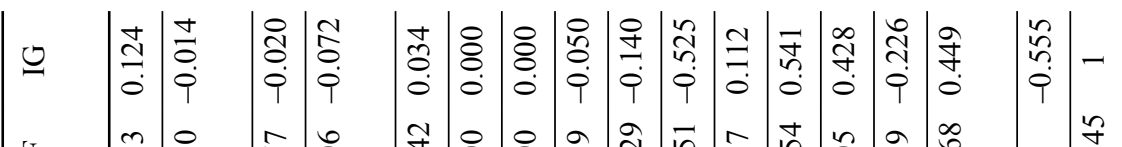

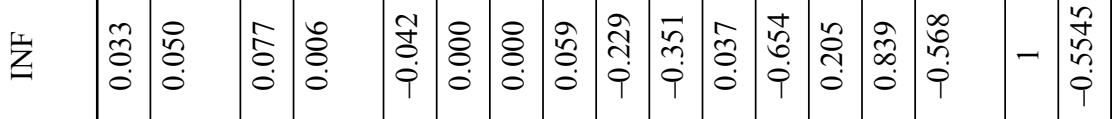

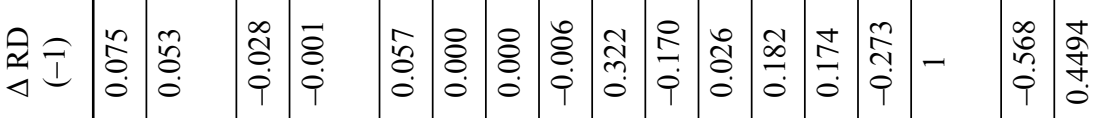

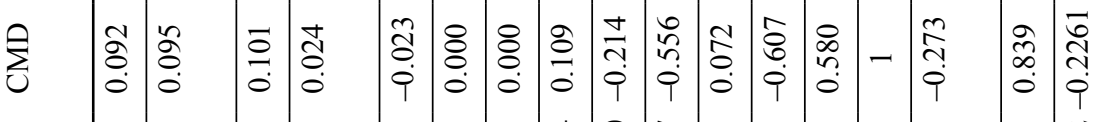

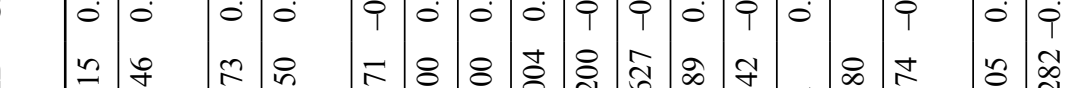

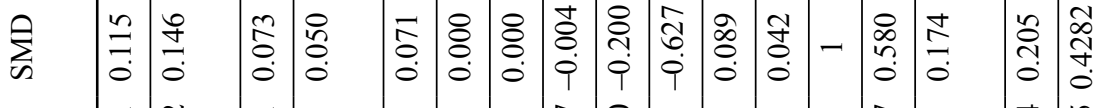

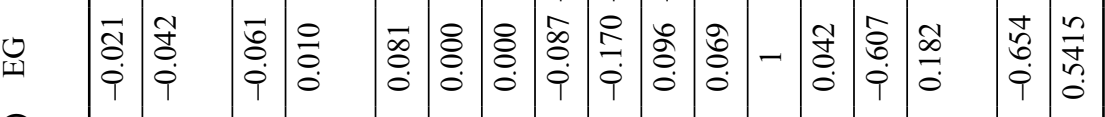

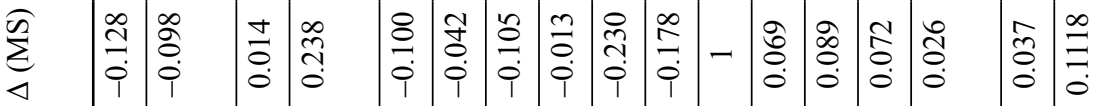

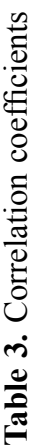

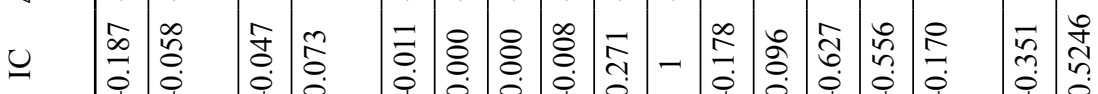

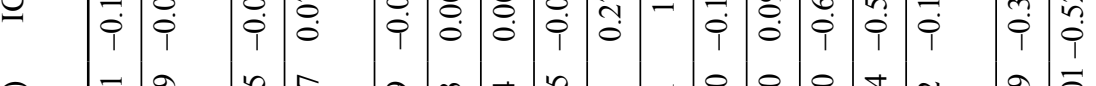

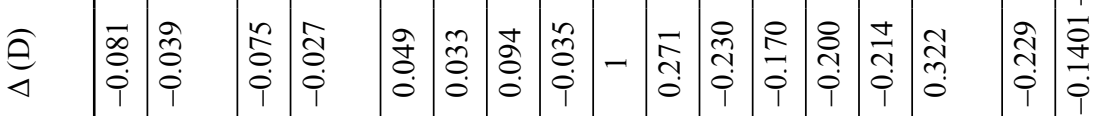

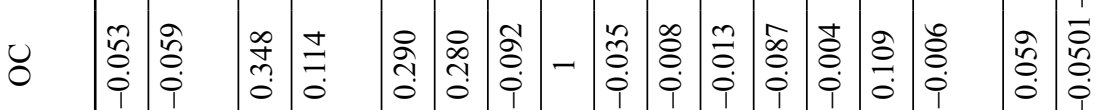

* = 8 त

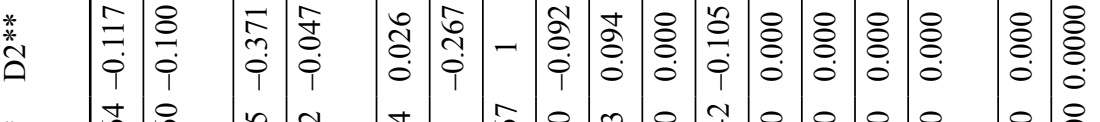

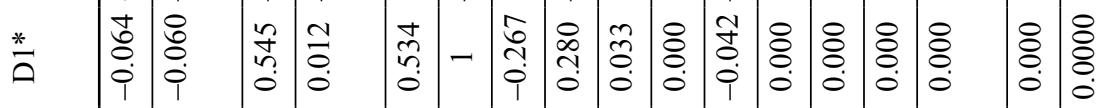

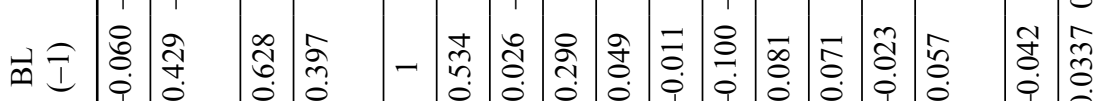

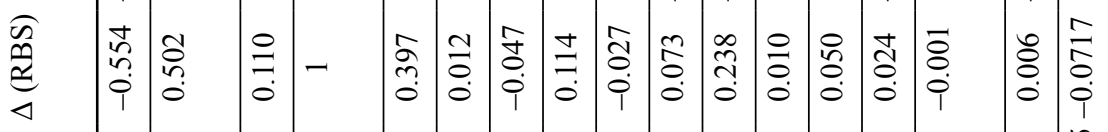

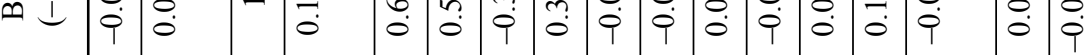

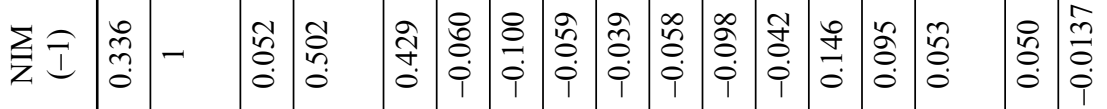

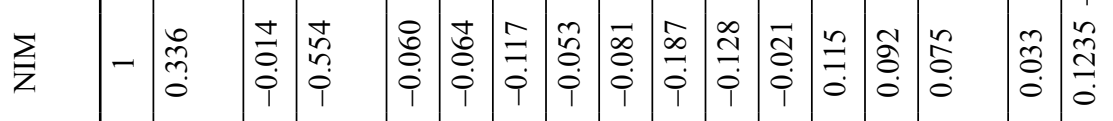

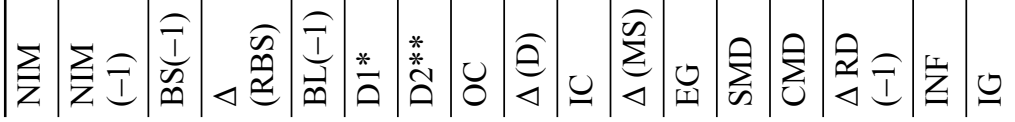


Table 4. Regression results

\begin{tabular}{|c|c|c|c|c|c|}
\hline & \multicolumn{5}{|c|}{$\begin{array}{l}\text { Dependent variable: NIM } \\
\text { Method: Panel EGLS (Cross-section weights) } \\
\text { Sample (adjusted): } 20032010 \\
\text { Periods included: } 8 \\
\text { Cross-sections included: } 26 \\
\text { Total panel (balanced) observations: } 208 \\
\text { Linear estimation after one-step weighting matrix } \\
\text { White cross-section standard errors \& covariance } \\
\text { (no d.f. correction) }\end{array}$} \\
\hline Variable & Symbol & Coefficient & Std. Error & $\mathrm{t}$-Statistic & Prob. \\
\hline Constant & $\mathrm{C}$ & -16.6096 & 3.0763 & -5.3992 & 0.0000 \\
\hline \multicolumn{6}{|c|}{ Bank- and bank industry-specific variables: } \\
\hline Net Interest Margin & $\operatorname{NIM}(-1)$ & 0.9559 & 0.0565 & 16.9250 & 0.0000 \\
\hline Bank Soundness & $\mathrm{BS}(-1)$ & 0.0191 & 0.0085 & 2.2527 & 0.0254 \\
\hline$\Delta$ Relative Bank Size & $\Delta(\mathrm{RBS})$ & -2.5960 & 0.3576 & -7.2603 & 0.0000 \\
\hline Bank Liquidity & $\mathrm{BL}(-1)$ & -0.0233 & 0.0085 & -2.7205 & 0.0071 \\
\hline Ownership & $\mathrm{D} 1 *$ & 0.0204 & 0.1876 & 0.1085 & 0.9137 \\
\hline Ownership & $\mathrm{D} 2 * *$ & -0.1322 & 0.1937 & -0.6824 & 0.4958 \\
\hline Operating Cost & $\mathrm{OC}$ & 0.0001 & 0.0000 & 7.6399 & 0.0000 \\
\hline$\Delta$ Diversification & $\Delta(\mathrm{D})$ & -0.0146 & 0.0068 & -2.1447 & 0.0332 \\
\hline Industry Concentration & IC & 0.0131 & 0.0022 & 5.8562 & 0.0000 \\
\hline$\Delta$ Market Share & $\Delta(\mathrm{MS})$ & 1.5087 & 0.2135 & 7.0681 & 0.0000 \\
\hline \multicolumn{6}{|c|}{ B. Macroeconomic/non-financial industry specific variables: } \\
\hline Economic Growth & EG & 0.0542 & 0.0407 & 1.3334 & 0.1840 \\
\hline Stock Market Development & SMD & -0.0132 & 0.0052 & -2.5272 & 0.0123 \\
\hline Credit Market Development & CMD & -0.0135 & 0.0128 & -1.0536 & 0.2934 \\
\hline$\Delta$ Real Depreciation & $\Delta \mathrm{RD}(-1)$ & 0.2472 & 0.0494 & 5.0087 & 0.0000 \\
\hline Inflation & INF & 0.3633 & 0.0711 & 5.1080 & 0.0000 \\
\hline \multirow[t]{10}{*}{ Industrial Growth } & IG & 0.2877 & 0.0522 & 5.5151 & 0.0000 \\
\hline & \multicolumn{5}{|c|}{ Weighted statistics } \\
\hline & R-squared & 0.8841 & Mean depe & endent var & 4.6679 \\
\hline & Adjusted R-squared & 0.8744 & S.D. deper & ndent var & 4.1871 \\
\hline & S.E. of regression & 1.2938 & Sum squal & red resid & 319.7368 \\
\hline & F-statistic & 91.0977 & Durbin-W & atson stat & 2.1969 \\
\hline & Prob(F-statistic) & 0.0000 & & & \\
\hline & \multicolumn{5}{|c|}{ Un-weighted statistics } \\
\hline & R-squared & 0.8621 & Mean depe & endent var & 2.9076 \\
\hline & Sum squared resid & 428.7025 & Durbin-W & atson stat & 2.4851 \\
\hline
\end{tabular}

Notes: *D1 = 1 for foreign bank (i.e. incorporated outside Pakistan) and 0 for a domestic bank (i.e. incorporated inside Pakistan); ${ }^{*} \mathrm{D} 2=1$ for a public sector bank and 0 for a private bank. 
Negative and statistically significant coefficient with stock market in our results negates complementarities hypothesis and confirms that stock market development as means of alternative source of finance has contributed to reduction in NIMs through reduction in concentration of market power in banking industry of Pakistan. On the other hand, negative but insignificant coefficient credit/banking sector development highlights the strong need for expansion of banking industry to break banking cartels and bring down NIMs. Our regression results suggest that real depreciation positively affects NIMs in Pakistan. Results of our model suggest that higher inflationary pressure is translated to higher NIMs in Pakistan. This also implies that banks pass on inflation dis-proportionately to depositors and borrowers. Our results are consistent with the findings in Tan (2012) but inconsistent with the results in Sidabalok and Viverita (2012), and Khawaja and Din (2007). Growing industry meets its financing needs to realize its expansion plans heavily from debt in addition to other means of financing thus raising demand for loans and resulting in upward push to NIMs in Pakistan. Heavy reliance of corporate sector on debt choice of finance is due to low financial distress costs in Pakistan particularly attributable to slow court procedures (Shah, Khan 2007).

Foreign banking sector is relatively very small in its size (only 5 banks in the sample) in Pakistan. Foreign banks' assets constitute less than 3\% of the banking industry's assets in Pakistan. However, Table 5 presents comparison of the effects of various explanatory variables on NIMs of local and foreign banks.

Signs and/or significance of coefficients of most of these variables on NIMs of local and foreign banks appear to be same (bank soundness, diversification, credit market development are a few exceptions). It is interesting to note that coefficient magnitudes sof most of the bank and bank industry-specific variables does not significantly vary while much variation exists in coefficient magnitudesof macroeconomic or non-financial industry-specific variables. 


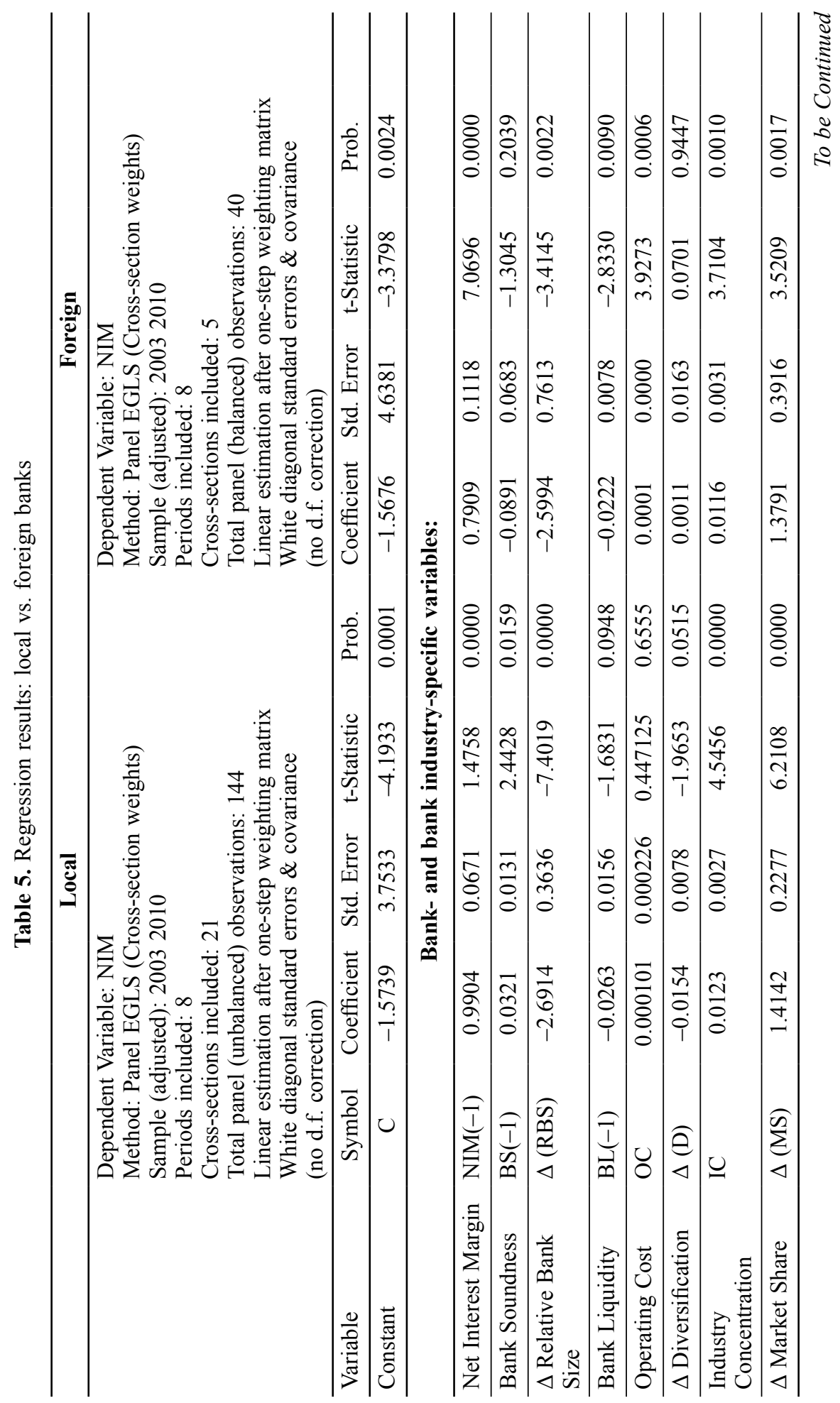




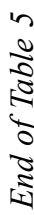

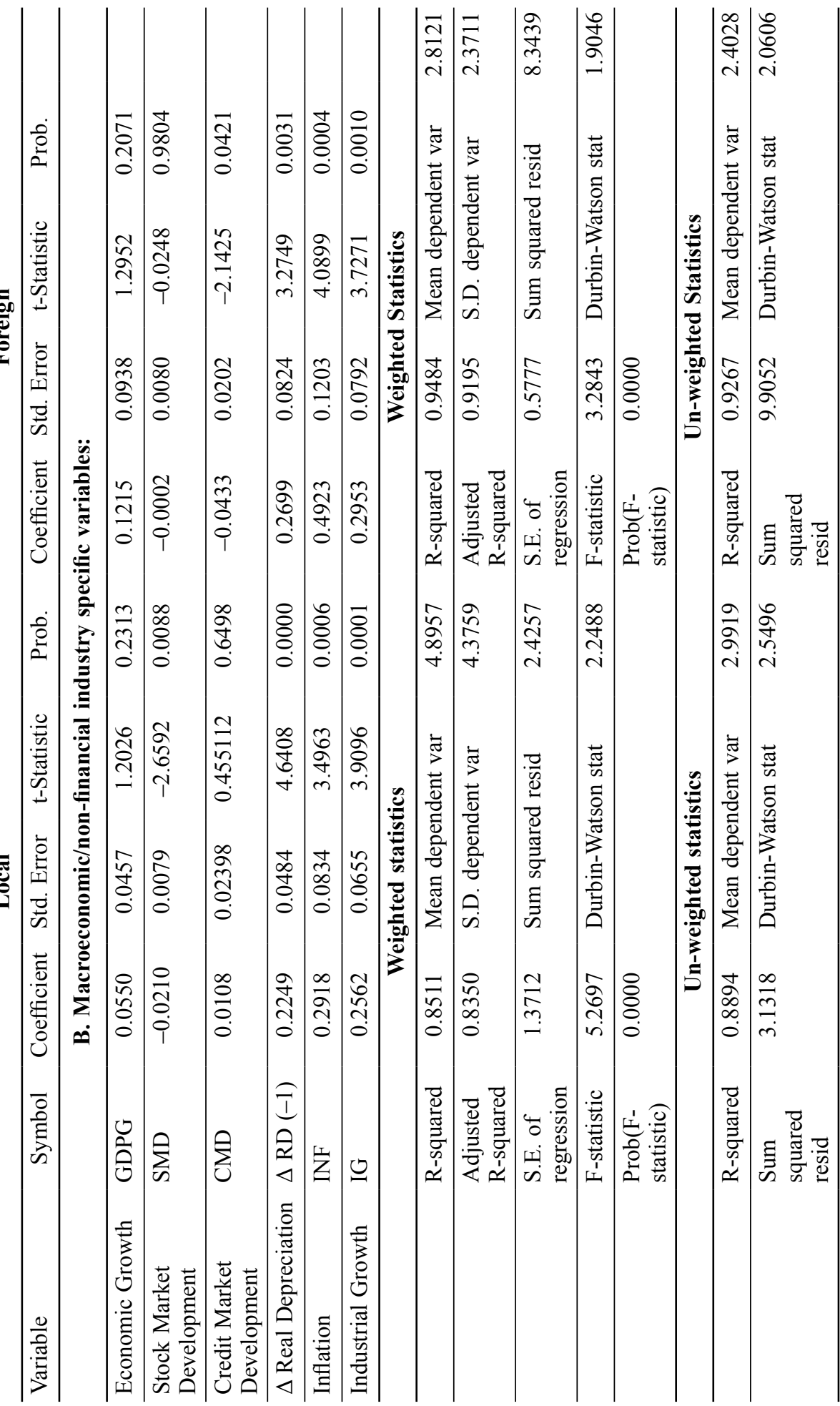




\section{Conclusions and policy implications}

All bank- and bank industry-specific variables excluding ownership and all macrocosmic and non-financial industry specific variables (excluding GDP and banking sector/ credit market development) have statistically significant influence on NIMs in Pakistan. Among former category of variables, past NIMs, bank soundness, operating cost, diversification, industry concentration, relative market share of a bank have positive impact while growth in bank size, lagged liquidity and public ownership have dampening effects on NIMs. Among later category of variables, GDP growth, inflation, real depreciation and industrial growth have positive coefficients while stock market and banking sector development has negative impact on NIMs in Pakistan.

Our results suggest that stock market development as means of alternative source of finance has contributed to reduction in NIMs through reduction in concentration of market power in banking industry of Pakistan. On the other hand, the impact of expansion of the banking industry (banking sector development) on breaking banking cartels and bringing NIMs down had been insignificant. This calls for further need for strong action of anti-trust authority. Exchange rate adjustments, rate of inflation and growth of the industry also cannot be ignored in management of NIMs.

Incentives for bank executives and managers to ensure efficiency in operating costs, reduction in the premium charged for bank soundness, diversification of bank activities and passing on the scale efficiencies to both depositors and borrowers can also play role to bring interest margins down to accelerate investment and growth in the country.

\section{References}

Angbazo, L. 1997. Commercial bank net interest margins, default risk, interest rate risk and offbalance sheet banking, Journal of Banking and Finance 21: 55-87.

http://dx.doi.org/10.1016/S0378-4266(96)00025-8

Aysan, A. F.; Dalgic, C. H.; Demirci, M. 2010. Macroeconomic, sector specific and bank specific determinants of net interest rate margin: what matters more for an emerging market economy, in EcoMod 2010 Conference [online], [cited 24 April 2012]. EcoMod Network. Available from Internet: http://www.ecomod.org/files/papers/1254.pdf

Banking Statistics of Pakistan. 2010. Statistics \& DWH Department of State Bank of Pakistan [online], [cited 01 March 2012]. Available from Internet: http://www.sbp.org.pk/publications/ anu_stats/2010.htm

Beck, T.; Demirgüç-Kunt, A.; Levine, R. 2000. A new database on financial development and structure, World Bank Economic Review 14: 597-605. http://dx.doi.org/10.1093/wber/14.3.597

Brock, P.; Rojas, L. 2000. Understanding the behavior of bank spreads in Latin America, Journal of Development Economics 63: 113-134. http://dx.doi.org/10.1016/S0304-3878(00)00102-4

Claeys, S.; Vennet, R. V. 2008. Determinants of bank interest margins in Central and Eastern Europe: a comparison with the West, Economic Systems 32(2): 197-216.

http://dx.doi.org/10.1016/j.ecosys.2007.04.001

Demirgüç-Kunt, A.; Huizinga, H. 1999. Determinants of commercial bank interest margins and profitability: some international evidence, The World Bank Economic Review 13(2): 379-408. http://dx.doi.org/10.1093/wber/13.2.379 
Demirgüç-Kunt, A.; Huizinga, H. 2000. Financial structure and bank profitability, World Bank Policy Research Working Paper 2430 [online]. The World Bank. Available from Internet: http:// elibrary.worldbank.org/docserver/download/2430.pdf?expires=1351603861\&id=id\&accname=gu est\&checksum $=66436$ AA40BFCA29F5879CD66ACC7624F

Demirgüç-Kunt, A.; Laeven, L.; Levine, R. 2003. Regulations, market structure, institutions, and the cost of financial intermediation, Working Paper No. 9890 [online], [cited 16 May 2012]. National Bureau of Economic Research. Available from Internet: http://ssrn.com/abstract $=427200$ http://dx.doi.org/10.2139/ssrn.427200

Doliente, J. S. 2005. Determinants of bank net interest margins in Southeast Asia, Applied Financial Economic Letters 1: 53-70. http://dx.doi.org/10.1080/1744654042000303629

Financial Stability Review. 2011. The European Central Bank [online], [cited 21 April 2012]. Available from Internet: http://www.ecb.europa.eu/pub/fsr/shared/pdf/ivbfinancialstabilityreview201112en.pdf?60b6d06373e7d99bfe8f1329f4c66e66

Financial Statements Analysis of Companies (Non-Financial) Listed at Karachi Stock Exchange, Various Issues. 2001-2010. Statistics and DWH Department. State Bank of Pakistan, Karachi.

Financial Statements Analysis of Financial Sector, Various Issues. 2001-2010. Statistics and DWH Department. State Bank of Pakistan, Karachi

Gelos, R. 2006. Banking spreads in Latin America, IMF Working Paper WP/06/44. International Money Fund.

Gounder, N.; Sharma, P. 2012. Determinants of bank net interest margins in Fiji, a small island developing state, Applied Financial Economics 22(19): 1647-1654.

http://dx.doi.org/10.1080/09603107.2012.674202

Hacker, R. S.; Kim, H.; Månsson, K. 2010. The relationship between exchange rate and interest rate differentials - a wavelet approach, CESIS Electronic Working Paper Series Paper No. 217 [online], [cited 23 April 2012]. The Royal Institute of Technology: Centre of Excellence for Science and Innovation Studies (CESIS). Available from Internet: http://papers.cesis. se/CESISWP217.pdf

Hadad, M. D.; Santoso, W.; Dwityapoetra, S. B. 2003. Intermediation cost study of some banks in Indonesia: is interest credit banks overpriced?, Bank of Indonesia Working Paper. Jakarta: Bank of Indonesia.

Hamadi, H.; Awdeh, A. 2012. The determinants of bank net interest margin: evidence from the Lebanese banking sector, Journal of Money, Investment and Banking 23: 85-98. [online], [cited 12 September 2012]. EuroJournals Publishing, Inc. Available from Internet: http://www. journalofmoneyinvestmentandbanking.com/ISSUES/JMIB_23_07.pdf

Hand Book on Statistics of Pakistan Economy. 2010. State Bank of Pakistan [online], [cited 10 March 2012]. Available from Internet: http://www.sbp.org.pk/departments/stats/PakEconomy_ HandBook/index.htm

Haruna, M. A. 2012. Determinants of cost of financial intermediation in Nigeria's pre-consolidated banking sector, International Journal of Advanced Research in Management and Social Sciences 1(2): 180-194. [online], [cited 12 September 2012]. Available from Internet: http:// garph.co.uk/IJARMSS/Aug2012/12.pdf

Hawtrey, K.; Liang, H. 2008. Bank interest margins in OECD countries, North American Journal of Economics and Finance 19: 249-60. http://dx.doi.org/10.1016/j.najef.2008.07.003

Ho, T.; Saunders, A. 1981. The determinants of bank interest margins: theory and practice, Journal of Financial and Quantitative Analysis 16: 581-600. http://dx.doi.org/10.2307/2330377

Igan, D.; Pinheiro, M. 2011. Credit growth and bank soundness: fast and furious?, IMF Working Paper WP/11/278. Washington: International Monetary Fund. 
Jayaatne, J.; Strahan, P. 1996. The finance-growth nexus: evidence from bank branch deregulation, Quarterly Journal of Economics 11: 639-670. http://dx.doi.org/10.2307/2946668

Khawaja, M. I.; Din, M. 2007. Determinants of interest spread in Pakistan, The Pakistan Development Review 46(2): 129-143. Islamabad: Pakistan Institute of Development Economics. [online], [cited 12 May 2012]. Available from Internet: http://www.jstor.org/stable/41260796

Khediri, K. B.; Ben-Khedhiri, H. 2011. Determinants of bank net interest margin in Tunisia: a panel data model, Applied Economics Letters 18: 1267-1271.

http://dx.doi.org/10.1080/13504851.2010.534052

Levine, R. 1997. Financial development and economic growth, Journal of Economic Literature 35(2): 688-726.

Männasoo, K. 2012. Determinants of bank interest spread in Estonia, Working Paper Series 1/2012 [online], [cited 13 September 2012]. Bank of Estonia. Available from Internet: http://www. eestipank.info/pub/en/dokumendid/publikatsioonid/seeriad/uuringud/2012/12012/wp112.pdf

Naceur, S. B.; Goaied, M. 2008. The determinants of commercial bank interest margin and profitability: evidence from Tunisia, Frontiers in Finance and Economics 5(1): 106-130 [online], [cited 12 September, 2012]. Available from Internet: http://ssrn.com/abstract=1538810

Rajan, R.; Zingales, L. 1998. Financial development and growth, American Economic Review 88: 559-586.

Poghosyan, T. 2012. Financial intermediation costs in low income countries: the role of regulatory, institutional and macroeconomic factors, IMF Working Paper No. WP/12/140. Internal Monetary Fund.

Saunders, A.; Schumacher, L. 2000. The determinants of bank interest rate margins: an international study, Journal of International Money and Finance 19: 813-832.

http://dx.doi.org/10.1016/S0261-5606(00)00033-4

Shah, A.; Khan, S. 2007. Determinants of capital structure: evidence from Pakistani panel data, International Review of Business Research Papers 3(4): 265-282.

Sidabalok, L. R.; Viverita. 2012. The Determinants of Banks'Net Interest Margin in Indonesia: A Dynamic Approach [online], [cited 25 February 2012]. Available from Internet: http://ssrn. com/abstract $=1990175$

Sufian, F.; Habibullah, M. S. 2009. Bank specific and macroeconomic determinants of bank profitability: empirical evidence from the China banking sector, Frontiers of Economics in China 4(2): 274-291 [online], [cited 13 September 2012]. Available from Internet: http://www.springerlink.com/content/e835h5t8q1k0m646/

Tan, T. B. P. 2012. Determinants of credit growth and interest margins in the Philippines and Asia, IMF WP/12/123. Washington: Asia and Pacific Department. International Monetary Fund.

The World Bank. 2012. World Development Indicators [online], [cited 12 April 2012]. Available from Internet: http://data.worldbank.org/country/pakistan

Ijaz HUSSAIN is an Economist and Associate Member of the Institute of Cost and Management Accountants of Pakistan. Ijaz Hussain is officiating Head of Department of Economics at School of Liberal Arts and Social Sciences at Beaconhouse National University, Lahore in Pakistan. He is also currently Research Fellow at Institute of Public Policy at Beaconhouse National University, Lahore. He has 15 years of teaching, research and administrative experience in reputed institutions of Pakistan including Aitchison College, Lahore, Government College University, Lahore and Beaconhouse National University, Lahore. His areas of interest include Managerial Economics, Accounting and Finance. 